\title{
Progress on stem cell research towards the treatment of Parkinson's disease
}

\author{
Stuart AJ Gibson', Guo-Dong Gao², Katya McDonagh ${ }^{3}$ and Sanbing Shen*3
}

\begin{abstract}
Parkinson's disease (PD) is a neurodegenerative disorder characterized by the progressive accumulation of Lewy body inclusions along with selective destruction of dopaminergic (DA) neurons in the nigrostriatal tract of the brain. Genetic studies have revealed much about the pathophysiology of PD, enabling the identification of both biomarkers for diagnosis and genetic targets for therapeutic treatment, which are evolved in tandem with the development of stem cell technologies. The discovery of induced pluripotent stem (iPS) cells facilitates the derivation of stem cells from adult somatic cells for personalized treatment and thus overcomes not only the limited availability of human embryonic stem cells but also ethical concerns surrounding their use. Non-viral, non-integration, or non-DNA-mediated reprogramming technologies are being developed. Protocols for generating midbrain DA neurons are undergoing constant refinement. The iPS cell-derived DA neurons provide cellular models for investigating disease progression in vitro and for screening molecules of novel therapeutic potential and have beneficial effects on improving the behavior of parkinsonian animals. Further progress in the development of safer non-viral/non-biased reprogramming strategies and the subsequent generation of homogenous midbrain DA neurons shall pave the way for clinical trials. A combined approach of drugs, cell replacement, and gene therapy to stop disease progression and to improve treatment may soon be within our reach.
\end{abstract}

*Correspondence: sanbing.shen@nuigalway.ie

${ }^{3}$ Regenerative Medicine Institute, School of Medicine, National University of Ireland Galway, Newcastle Road, Galway, Ireland

Full list of author information is available at the end of the article
Parkinson's disease (PD) affects approximately $1 \%$ of the global population over 50 years of age and is second only to Alzheimer's disease in prevalence. Clinical diagnosis relies on the identification of a number of classic symptoms associated with the disease and the progressive decline in motor function, including bradykinesia, rigidity, rest tremor, and postural instability [1]. The main neuropathology of PD includes the accumulation of Lewy bodies and loss of dopaminergic (DA) neurons. Lewy bodies are misfolded protein aggregates usually containing $\alpha$-synuclein, which is used as a characteristic neuropathological feature in sporadic cases. An increase in the dose of the SNCA gene, encoding $\alpha$-synuclein, causes a fully penetrant and aggressive form of PD. The loss of DA neurons in PD is specific to the midbrain region that projects from the substantia nigra pars compacta (SNpc) to the striatum $[1,2]$.

Although 10 different subtypes of DA neurons have been identified in the whole brain, only three of them (A8, A9, and A10) reside in the midbrain and these are developed from mesencephalic tissue of fetuses [3]. The A8 and A10 subtypes supply the ventral tegmental area (VTA) and retrorubral area, which form the emotion and reward components of the limbic system. Of particular relevance to $\mathrm{PD}$ are the $\mathrm{SNpc}$ A9 subtype neurons, which project to the striatum to form the nigrostriatal pathway and are involved in the control of movement [3].

SNpc A9 DA neurons can be distinguished from the VTA A10 subtype. The A9 neurons express G proteincoupled inward-rectifying current potassium type 2 (GIRK2), whereas A10 neurons express calbindin [4]. Interestingly, the axonal projection patterns of DA neurons are very different when they are grafted into adult mice. When retrograde axonal tracing is used, GIRK2+ A9 neurons are found to provide nearly all of the striatal innervation whereas the calbindin ${ }^{+}$A10 neurons grow toward the frontal cortex [4]. These results imply that the axons of different midbrain DA neurons respond differently to guidance cues and this further highlights how crucial it is to understand different subtypes of DA neurons and the uniqueness of A9 DA neurons for the treatment of PD. Currently, it is unknown what molecules are involved in the specification of A9 or A10 neurons; 
however, we have begun to understand why the A9 subtype is more vulnerable to degeneration. Guzman and colleagues [5] showed that A9 (not A10) DA neurons engaged plasma membrane L-type calcium channels throughout the pacemaking cycle. Knocking out DJ-1 (PARK7) downregulates the expression of uncoupling proteins, compromises calcium-induced uncoupling, and increases oxidation of matrix proteins specifically in A9 neurons. Therefore, A9 neurons are dying of high oxidative stress due to high calcium fluxes [5]. As PD is associated with the destruction of the A9 neurons located in the nigrostriatal tract, a straightforward approach to cure the disease may be to generate A9 DA neurons to reconstruct and provide reinnervation to the striatum.

\section{Stem cell grafts in patients with Parkinson's disease and in animal models}

Although early clinical trials were limited in size and number, they did highlight the therapeutic potential of stem cells for neurodegenerative diseases. In 1995, Kordower and colleagues [6] grafted fetal mesencephalic tissue harvested from a total of seven human embryos (at ages of 6.5 to 9 weeks) into the post-commissural putamen of a patient with PD. Up to 18 months after the procedure, not only did these bilateral grafts survive and remain viable but also there was marked DA reinnervation in the striatum. It was observed, through a series of positron emission tomography (PET) scans, that fluorodopa uptake increased markedly after 6 and 12 months, respectively, and this would reflect improved neuronal function in the region surrounding the transplanted tissue. The transplant recipient exhibited motor abilities and considerable improvement in the Unified Parkinson's Disease Rating Scale (UPDRS) test [6]. A similar trial reported further clinical benefit and provided the opportunity for complete withdrawal of L-DOPA (L3,4-dihydroxyphenylalanine) treatment [7]. However, some other studies had poorer clinical responses [8,9], and a smaller number of grafted DA neurons or severe stages of the disease or both were considered to be the causes [10]. More recently, an improvement was ascertained in subpopulations of these same patients upon post hoc analysis [11].

Thus, the long-term effects of stem cell transplantation therapy have been difficult to evaluate because of a combination of limited clinical trials, the typically late onset of the disease, and the fact that clinical follow-ups have been conducted mostly within an 18-month period [11]. Piccini and colleagues [7] found that, 10 years after transplantation, there was continuous benefit, and the patient had no rigidity but only 'minor hypokinesia'. However, Kordower and colleagues [11] analyzed the longest-surviving transplant patient, 14 years after the operation, and observed a low UPDRS in the first
10 years, but the patient experienced gait problems, difficult balancing, and falls from 11 years after transplantation. On post-mortem analysis, the grafts were found to have Lewy body-like structures, staining positively for $\alpha$-synuclein and ubiquitin, strongly suggestive of a PD progression in the patient after transplantation [11]. These findings raise the possibility that transplanted grafts are not invincible to damage by PD progression. Side effects were also associated with fetal mesencephalic grafts, and dyskinesia was a particular problem $[8,9]$. Additionally, fetal grafts have not been able to fully reconstruct the nigrostriatal tract [10], highlighting the need for differentiated A9 DA neurons (rather than neural stem cells from fetal brain) for the therapy of PD [4].

The limited availability of human embryonic tissue for transplantation has driven researchers to investigate alternative sources of stem cells. For example, adult mesenchymal stem cells were exploited in an MPTP mouse model of PD [12]. Five weeks after transplantation, 5-bromo-2'-deoxyuridine (BrdU)-labeled mesenchymal transplants were reported to express tyrosine hydroxylase $(\mathrm{TH})$, the rate-limiting enzyme of DA synthesis. Mice had significantly improved performance on the rotarod test. Uncommitted neural stem cells from the subventricular zone of adult brain were extracted and investigated for TH neuronal differentiation [13]. This line of research may provide information for promoting endogenous neurogenesis but may not be realistic for supplying donor cells for cell replacement therapy.

Establishment of human embryonic stem (hES) cells, with their unlimited differentiation potential, offers unequivocal prospects for regenerative medicine [14]. Before hES cells can be considered clinically, we must demonstrate that they provide long-term improvements in motor function and mobility in addition to alleviating symptoms of drug resistance in animal models. The most commonly used PD models in animal trials are generated by using 6-hydroxydopamine (6-OHDA), a neurotoxin that selectively induces extensive degeneration of striatal DA neurons via apoptotic and necrotic pathways in rodents [15-22]. The success of the transplantation experiments is measured by behavioral improvements in the amphetamine- or amorphine-induced rotation behavioral test, adjusting step test, the cylinder test, and the paw-reaching test, along with immunohistochemical evidence for the survival and integration of grafts within host brains $[15,16,20]$.

The therapeutic potential of ES cells has been reflected in numerous animal trials, which are largely encouraging. Björklund and colleagues [23] demonstrated that ES cells injected stereotactically into the striatum of rat models of PD differentiated into DA neurons spontaneously, along with the development of some $5-\mathrm{HT}^{+}$neurons that were 
shown to increase synaptic DA release [24]. PET and magnetic resonance imaging, in addition to histological examination at the endpoint of animal trials, revealed the integration of the ES cell-derived neurons. The resulting regeneration of DA neural networks in the striatum correlated with an improvement of the rat models in behavioral tests [23]. In a sham-controlled trial, Kim and colleagues [20] (2002) reported that rats grafted with ES cell-derived DA neurons showed significant improvements in several behavioral tests and that the cells exhibited electrophysiological properties typical of midbrain DA neurons. Similar results were elicited when hES cell-derived DA neurons were enriched by co-culture with immortalized midbrain astrocytes and grafted into 6-OHDA-lesioned rats [15]. Transplantation of grafts composed mainly of the A9 subtype DA neurons $\left(\mathrm{GIRK} 2^{+}\right)$led to substantial functional improvement [15]. In contrast, Brederlau and colleagues [17] (2006) observed no improvement in the motor symptoms of 6-OHDA-lesioned rats grafted with hES cell-derived cells. This was interpreted as being caused by the lack of sufficient $\mathrm{TH}^{+}$cells from a stromal cell-derived inducing activity (SDIA) protocol [17]. The number of DA neurons is indeed reported to correlate directly with the outcome of behavior [16]. However, concerns surrounding immune rejection of the grafts and ethical issues together with a shortage of supply have severely curtailed investigation of hES cells for clinical applications.

A groundbreaking technology has recently emerged in the field of regenerative medicine. Takahashi and colleagues showed that fibroblasts harvested from either mice [25] or humans [26] can be converted into induced pluripotent stem (iPS) cells in culture via viral transduction of four transcription factors: Oct4, Sox2, Klf4, and c-Myc. These iPS cells make it possible to bypass hES cells, to treat patients with their own somatic cell-derived stem cells (Figure 1), and (in theory) to avoid immune rejection caused by patient-donor cell incompatibility [18]. iPS cells have been shown to display properties similar to those of ES cells [22,25]. For example, Swistowski and colleagues [22] compared iPS cells with hES cells and concluded that the two had similar genomic stability, transcription profiles, pluripotency, and DA neuron differentiation capacity. Several groups have succeeded in generating DA neurons from iPS cells independently $[18,21,22,27]$. iPS cell-derived DA neurons were shown to integrate into the striatum of parkinsonian rats with behavioral improvements comparable to those observed using ES cell-derived DA neurons [18,21,22].

As in the case of ES cells, teratoma may be formed if iPS grafts are not fully differentiated [18]. Brederlau and colleagues [17] (2006) found that the time spent during in vitro pre-differentiation via the SDIA method could make a noteworthy impact on teratoma formation: rats developed severe tumors with hES cell grafts predifferentiated for 16 days; extending this length of time to approximately 20 to 23 days in culture resulted in teratoma-free rats mostly. When SSEA1 ${ }^{+}$(a marker for pluripotent stem cells) cells were removed from mouse iPS cell-derived neurons by cell sorting, no teratoma was formed in any of the rats 8 weeks after transplantation [18]. Therefore, the safety issue can be alleviated if homogenously post-mitotic cells are made prior to transplantation.

\section{Protocols used to generate midbrain dopaminergic neurons}

In light of the fact that hES cell differentiation favors a telencephalic fate, protocols have been designed to direct stem cell differentiation toward a mesencephalic fate [27]. Currently, there are two main methods to generate midbrain DA neurons: using stromal cell-derived feeder cells or defined culture media. A stromal cell-derived feeder line, PA6, from mouse skull bone marrow was found to promote DA neuron generation from hES cells [28]. However, the molecular nature of the SDIA is still unknown [29]. SDIA directs stem cells to become neural precursors, which then go through regional specification with floor plate-derived sonic hedgehog (SHH) and fibroblast growth factor 8 (FGF8). Wernig and colleagues [18] (2008) found that, once these factors were withdrawn, most cells differentiated into $\mathrm{Tuj}^{+}$neurons but that only a small fraction became $\mathrm{TH}^{+} \mathrm{DA}$ neurons. However, the proportion of $\mathrm{TH}$ neurons generated was increased with the length of the time they spent in culture [19].

Perrier and colleagues [30] described a protocol to produce approximately $24 \%$ to $40 \%$ of $\mathrm{TH}^{+}$neurons from ES cells in 6 weeks by culturing clusters of rosettes in stromal feeder conditions with SHH, FGF8, glial cell linederived neurotrophic factor (GDNF), dibutyryl cAMP, and transforming growth factor beta 3 (TGF 33 ). Vazin and colleagues [31] shortened the protocol to 1 month and the outcome was similar. They co-cultured hES cells with PA6 cells for 12 days and further differentiated them for 18 days with SHH, FGF8, and GDNF, and 34\% of cells became $\mathrm{TH}^{+}$. However, more efficient homogenous DA neuron production is desired. Stromal feeder cells are of animal origin and may retain xenogenic factors such as mouse antigens or pathogens or both, and these concerns prevent their use in clinical applications.

Efficient protocols have been developed for the derivation of DA neurons from $\mathrm{hES}$ cells by using defined culture media. For example, Cho and colleagues [19] developed a feeder-free method, with which $67 \%$ of hES cells became $\mathrm{TH}^{+} \mathrm{DA}$ neurons. This protocol involves a number of steps. After the formation of embryoid bodies (EBs) through the culture of hES cells in a non-adherent 


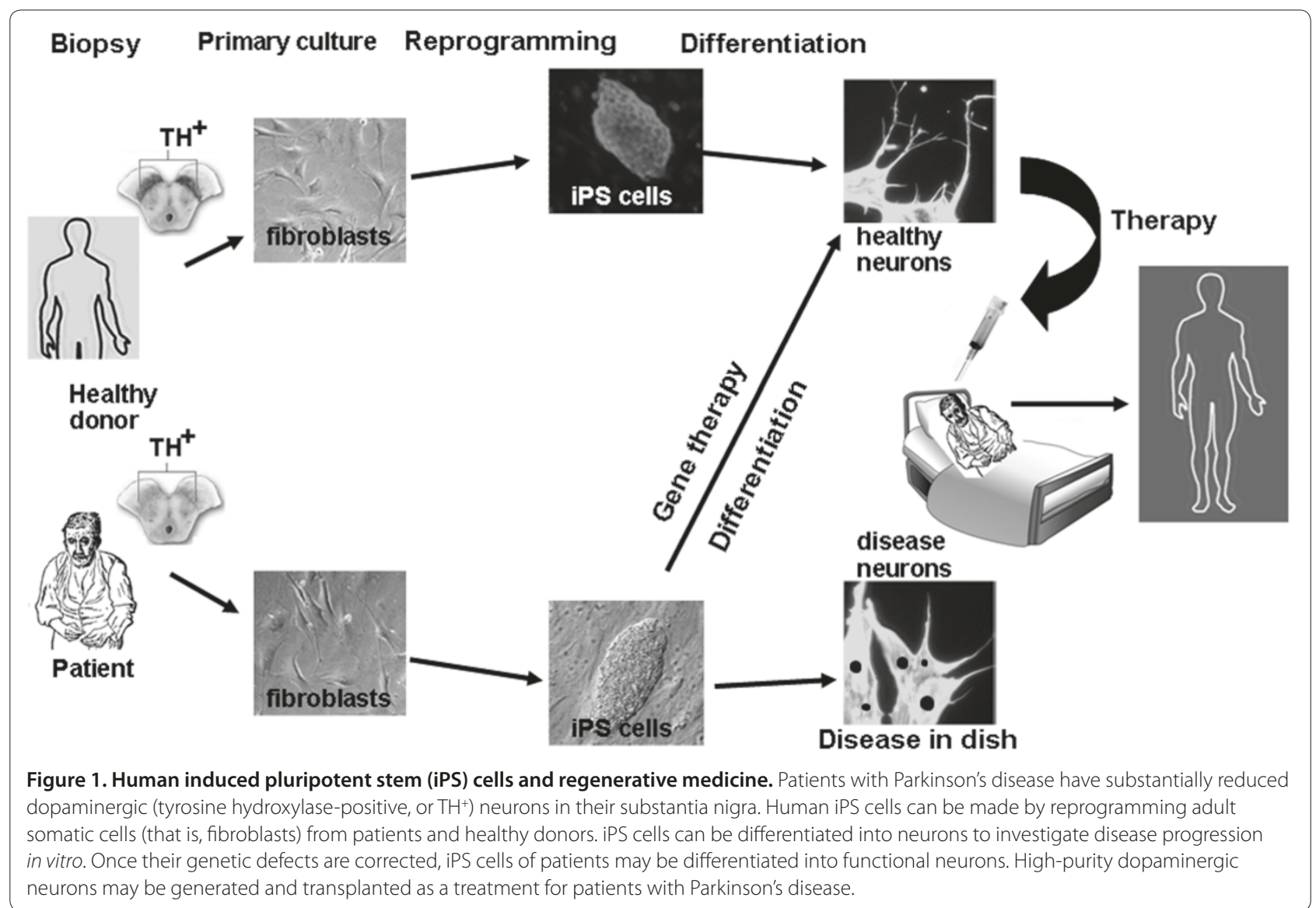

culture dish for 7 days, the EBs are transferred to a Matrigel-coated dish and cultured with $0.5 \% \mathrm{~N}_{2}$ supplement for 5 days to select for neural precursors. At this point, basic fibroblast growth factor is added to the culture for 14 days to promote the formation of spherical neural masses, which are transferred to a Matrigel-coated dish and incubated in defined differentiation media. Growth factors SHH and FGF8 are added to the medium for 10 days to promote neuronal induction and subsequently the cells are incubated with ascorbic acid for a further 6 days to promote DA maturation. This protocol has proven to be quite successful in the generation of DA neurons; $77 \%$ of the hES cells became neurons $\left(\mathrm{Tuj}^{+}\right)$, and $86 \%$ of $\mathrm{Tuj}^{+}$cells became $\mathrm{TH}^{+}$DA neurons [19].

$\mathrm{TH}$ is a rate-limiting enzyme in synthesizing dopamine and is an important marker for localizing DA neurons in the brain. However, TH marker alone may not be specific enough if A9 specific DA neurons are to be generated for the treatment of PD [3] since correct transcription factor expression is essential to the maintenance, differentiation, and survival of the DA neurons throughout their development [3]. At the progenitor stage, neural precursor cells are known to express Otx2, Lmx1a/b, Engrailed 1/2, Msx1/2, Neurogenin 2, and Mash1 [3]. As they mature, these cells continue to express En1/2 and Lmx1a/b but also start to express nuclear receptor-related 1 protein (NURR1) and pituitary homeobox 3 (PITX3). NURR1 (or NR4A1) is a member of the steroid/thyroid hormone/ retinoid receptor superfamily and critical for DA maintenance, whereas PITX3 is a paired homeodomain transcription factor that is important for $\mathrm{TH}$ expression and survival of SNpc A9 DA neurons [3]. It is unknown whether SNpc A9 and VTA A10 progenitors differ at the progenitor stage. The earliest distinction within midbrain DA development appears to be that ventro-lateral DA neurons express PITX3 before TH, whereas dorso-medial ones express TH before PITX3 [3]. Subsequently, A9 neurons also express GIRK2 specifically whereas A10 neurons express calbindin-D 28K [15].

Cooper and colleagues [27] (2010) reported that another transcription factor, FOXA2, a key marker of floor plate development, is required to specify and maintain ventral DA phenotype. Previous protocols were not able to generate FOXA2 ${ }^{+}$cells. An early exposure to retinoic acid improved regional specification and - in combination with a high activity of SHH, FGF8a, and WNT1 - gave 'robust differentiation' of FOXA2 ${ }^{+}$DA neurons [27]. Fasano and colleagues [32] showed that early high-dose 
SHH (125 to $500 \mathrm{ng} / \mathrm{mL}$ ) could also induce FOXA2 expression for successful midbrain DA neuron derivation from hES cells. Kriks and colleagues [33] used a floor plate-based strategy to obtain engraftable midbrain DA neurons that coexpressed TH with FOXA2, PITX3, and NURR1. The in vivo survival and function of the neurons were demonstrated in mouse, rat, and monkey PD hosts. This shows, for the first time, that hES cell-derived transplants may be feasible.

Additionally, evidence has emerged that post-transcriptional and post-translational modifications play a role in DA neuron phenotype. For example, the leucine-rich repeat kinase 2 (LRRK2) gene is frequently mutated in PD, and LRRK2 phosphorylates/inactivates eukaryotic initiation factor $4 \mathrm{E}$-binding protein (4E-BP). 4E-BP is a translation inhibitor and its chronic inactivation by mutant LRRK2 deregulates protein translation, eventually resulting in loss of DA neurons [34]. When the Drosophila homolog of 4E-BP, Thor, is overexpressed, it imposes a limit on DA neuron loss in Parkin and Pink1 mutant flies [35]. Pharmacological activation of $4 \mathrm{E}-\mathrm{BP}$ by rapamycin also prevents parkinsonian DA neuron loss [35].

Micro-RNAs (miRNAs) have also been implicated in DA development. These non-coding 18- to 25-base mRNAs regulate gene expression post-transcriptionally by binding to specific mRNA targets, leading to mRNA degradation or translational inhibition. Dicer is an enzyme critical for miRNA biosynthesis from larger transcripts. When Dicer is conditionally knocked out in mice by Wnt1 promoter-driven Cre recombinase, it produces deformities of the midbrain, cerebellum, and mandible and almost complete elimination of midbrain $\mathrm{TH}$ neurons together with a lack of miR-9, miR-124, and miR-218 expression [36]. This highlights the importance of miRNAs in DA neuron production. Significantly, using quantitative polymerase chain reaction (PCR), Kim and colleagues [37] demonstrated that a particular miRNA, miR-133b, is specifically expressed in midbrain DA neurons and is downregulated in the midbrain of patients with PD. This causes the loss of nigrostriatal DA neurons because miR-133b normally functions to repress PITX3 expression as part of a feedback loop. Two other miRNAs, miR-7 and miR-153, are involved in maintaining the $\alpha$-synuclein level $[38,39]$, and accumulation of $\alpha$ synuclein is the main pathological feature of PD. These miRNAs bind specifically to the 3' untranslated region of SNCA mRNA and downregulate production of $\alpha$-synuclein protein. The repression of $\alpha$-synuclein by miR-7 has been shown to be protective against oxidative stress and apoptosis of DA neurons in the striatum [39]. These studies suggest that regulation at post-transcriptional and posttranslational levels may represent viable therapeutic approaches for PD. An understanding of miRNA involvement in the maintenance of neurons is critical to the use of stem cell-derived DA neurons as a viable therapy for patients with PD.

\section{Direct reprogramming of dopaminergic neurons from somatic cells}

Recent research showed that somatic mouse cells can be converted directly to other cell types (that is, DA neurons) by expressing defined transcriptional factors. Using a two-step approach, Pfisterer and colleagues [40] first converted human embryonic fibroblasts, fetal lung fibroblasts, or post-natal fibroblasts into neurons by overexpression of Mash1 (also known as Ascl1), Brn2, and $M y t 1 l$ in lentiviral vectors. The converted neurons were subsequently directed to become DA neurons with expression of $L m x 1 a$ and FoxA2. In addition, Caiazzo and colleagues [41] showed that three transcription factors Mash1, Nurr1, and Lmx1a - were able to reprogram mouse and human fibroblasts directly into functional DA neurons, which release dopamine and exhibit regular electrical activity. This can be done by using prenatal and adult fibroblasts of healthy donors or of patients with PD [41]. Subtype-specific induced neurons derived from human somatic cells can be valuable for disease modeling and cell replacement therapy. However, this approach has limitations. Genetic modification is needed to introduce the defined set of transcription factors. The number of neurons that can be generated is strictly dependent on the number of initial fibroblasts from the donor and the efficiency of direct conversion. The capability of directly converted neurons in ameliorating the phenotype in animal models remains to be seen. Nevertheless, the whole process does not proceed via a pluripotent cell intermediate, and one may speculate that it may offer a reduced risk of tumor formation in transplantation.

\section{Refinement of induced pluripotent stem cell technology}

Since the publication of the first iPS cell generation in 2006, substantial progress has been made to improve the technology. To reduce multiple chromosomal integration sites associated with the initial four retroviral vectors, a single lentiviral reprogramming vector was developed to fuse them into a single open reading frame via selfcleaving 2A sequences [42]. Continuous expression of transgenes in iPS cells (even at low levels) might induce tumor formation in vivo [43] or alter differentiation potential. Soldner and colleagues [44] (2009) then developed a Cre recombinase excisable system to remove transgenes after reprogramming via doxycycline-inducible lentiviral transduction. Non-viral methods have been developed for mouse iPS cell generation. Kaji and colleagues [45] (2009) replaced viral vectors with a single plasmid vector expressing the four reprogramming factors linked with 2A peptides. Surprisingly, many iPS colonies 
differentiated spontaneously after Cre recombinasebased removal of the reprogramming factors. Co-transfection of two piggyBac transposons enhanced stable transfection efficiencies of human fibroblasts [45]. The problem of leftover sequence residues remains.

Non-integrative approaches were subsequently reported. Okita and colleagues [46] (2008) generated iPS cells at a low efficiency by repeated transfection of two circular plasmid vectors, and as a result of the approach, most iPS clones were free of plasmid integration. Similarly, Yu and colleagues [47] (2009) took advantage of the Epstein-Barr virus to generate iPS cells free of vector or transgene sequences. OriP/EBNA1 from the Epstein-Barr virus functions as stable extrachromosomal replicon and replicates plasmid once per cell cycle under selection. In the absence of drug selection, the episomes are lost at a rate of approximately 5\% per cell generation because of defects in plasmid synthesis/partitioning. However, this system required three plasmids carrying seven factors, including SV40 large T antigen. It has not been shown to work with adult fibroblasts yet, and expression of the EBNA1 protein may raise concerns of immune rejection if the vector is retained in the reprogrammed cells [46].

An increased expression of reprogramming factors should improve iPS efficiency, and removal of plasmid vector sequence could greatly increase transgene expression in mammalian cells. Jia and colleagues [48] (2010) took advantage of the øC31-based intramolecular recombination system to produce minicircle DNA expressing OCT4, SOX2, LIN28, and NANOG under a CMV promoter. The presence of an inducible phage $\varnothing \mathrm{C} 31$ integrase gene and attB/attP sites enables the generation of two circular plasmids: a minicircle reprogramming cassette and a plasmid backbone. The latter is linearized and degraded in bacteria. Thus, minicircle DNA can be purified and repeatedly transfected into somatic cells. Jia and colleagues [48] (2010) used this to generate iPS cells from human adipose cells, and the overall reprogramming efficiency was approximately $0.005 \%$. This is approximately half that of typical viral methods (approximately $0.01 \%$ ) but significantly higher than that of other plasmid vectors [48].

Because of the oncogenic potential, Klf4 and c-Myc were replaced by Nanog and Lin28 [49]. iPS cells could still be generated from mouse and human fibroblasts without c-Myc but at a severely reduced efficiency [50]. Furthermore, Kim and colleagues were able to reprogram adult mouse [51] and human fetal [52] cells with Oct4 only. Unfortunately, overexpression of Oct4 [53] and Klf4 [54] could be linked with dysplasia. Therefore, non-DNA approaches are sought to overcome the hurdles in iPS cell derivation. Supplementation of transcription factors to the culture medium has been tried out $[52,55,56]$. Transportation of the transcription factors from medium to cytoplasm and to nuclei was essential, and the reprogramming factors were therefore engineered to fuse with a poly-arginine transduction domain for human proteininduced iPS cells $[52,56]$. This method eliminates the risk of genetic modification but is very time-consuming. However, Rhee and colleagues [57] (2011) were able to generate DA neurons from protein-induced iPS cells in affluent quantities, and DA neurons were robust in survival compared with virus-derived human iPS cells and also produced prominent behavioral improvements in 6-OHDA-lesioned rats. Meanwhile, substantial progress has been made in improving iPS cell production by using small molecules. A cocktail of compounds, including PD0325901 (MEK inhibitor), CHIR99021 (GSK-3 inhibitor), A83-01 (TGF $\beta$ type I receptor ALK-5 inhibitor), and HA-100 (ROCK inhibitor), was shown to increase the reprogramming efficiency of an episomal vector by a factor of approximately 70 [58]. A kinase inhibitor, kenpaullone, can substitute for Klf4 [59]. E616452 and valproic acid - a TGF $\beta$ receptor ALK4/5/7 inhibitor and a histone deacetylase (HDAC) inhibitor, respectively - have also been used effectively to replace Sox2 [60]. Excitingly, a single molecule, RG108, a DNA methyltransferase inhibitor, is sufficient to reprogram mouse myoblasts with 5 days of treatment [61]. Whether human iPS cells can be made by using only small molecules remains a question.

\section{Disease 'in a dish'}

One of the advantages of iPS cells and ES cells is that they offer opportunities to visualize disease progression in vitro, which otherwise may be difficult to observe, by comparing neurons from healthy donors with those derived from patient cells (Figure 1). It is not well understood how the defective proteins aggregate in PD or indeed how they relate to the oxidative stress and specific cell destruction during PD progression [62]. Except in rare forms of defined genetic causes that constitute $5 \%$ to $10 \%$ of the incidence of PD, the etiology of the disease is not fully understood [63]. Genetic alterations can be made in ES/iPS cells by knockout, knocking in, inducible expression, or overexpression to mimic the genetics in patients. This will allow investigation of the disease progression of the neurological conditions in vitro.

Derivation of iPS cells from patients with known genetic defects can avoid genetic manipulation of iPS/ES cells, which is time-consuming and sometimes technically challenging. PD can be caused by defects in many loci, such as SNCA encoding $\alpha$-synuclein, LRRK2 encoding leucine-rich repeat kinase 2, Parkin (or PARK2) encoding the ubiquitin E3 ligase, PINK1 for PTENinduced kinase 1 , and $D J-1$ encoding a protein of the peptidase C56 family [64]. Availability of iPS cells from these patients will enable researchers to characterize 
effects of individual genetic components and to enhance the current understanding of PD pathophysiology. These iPS cells should incorporate all aspects of the pathophysiology and thus, in theory, should generate disease models that are more accurate than those using 6-OHDA or MPTP to destroy DA neurons.

Heterogeneity of iPS cell lines can be a problem in phenotyping iPS cells. Soldner and colleagues [65] (2011) have sought to find an effective way of studying PD progression by using zinc-finger nuclease-mediated genome-editing technology to generate ES/iPS cells carrying A53T (G209) or E46K (G188A) point mutations in the SNCA gene. Because of the slow progression of the pathological cellular events and late onset of the disease, the in vitro phenotype may be difficult to recognize if it is not carefully compared with closely matched controls. A lack of genetically matched controls (that is, non-affected sibling donors) could make it more difficult to determine whether the changes are relevant to the prevalent disease phenotypes, background, incomplete penetrance, age of onset, or nature of disease progression [65]. To ensure that the point mutations were the only modified variable in their study, Soldner and colleagues [65] either derived iPS cells from patients carrying the mutations and corrected them genetically as controls or produced the point mutations in wild-type hES cells.

However, it is encouraging that disease-related phenotypes are recaptured in iPS cell-derived neurons in some cases. For example, Devine and colleagues [66] (2011) generated multiple iPS cell lines from SNCA triplication patients. When these iPS cells were differentiated into midbrain DA neurons, patient-derived cells expressed increased $\alpha$-synuclein with relatively lower levels of paralogous proteins SNCB and SNCG. This precisely recapitulated the situation in these individuals [66]. Nguyen and colleagues [67] (2011) generated iPS cells carrying the most common PD-related G2019S mutation of the LRRK2 gene. Neurons from the mutated iPS cells express increased $\alpha$-synuclein and oxidative stressresponse proteins MAO-B and HSPB1. These neurons are also more susceptible to caspase- 3 activation and cell death when exposed to various stress agents (for example, MG132 and 6-OHDA) which are known to induce DA degeneration [67]. Such reproducible phenotypes from affected iPS cell-derived neurons will offer opportunities to examine disease progression in vitro as well as to use them as cellular models for screening compounds that may reverse the pathological phenotypes.

\section{Limitations and practicalities of induced pluripotent stem cells}

An overwhelming number of publications demonstrate that iPS cells are similar to ES cells, and both can be differentiated into cell types of three germ layers.
However, some recent studies suggest that there may be subtle differences between them. For example, in a comparison study, iPS cells were found to be less flexible in their differentiation capacity: only the blood-derived iPS cells showed potential in hematopoietic differentiation, whereas the fibroblast-derived iPS cells favored the osteogenic route [68]. Feng and colleagues [69] (2010) used an SDIA protocol to compare the growth and differentiation of both hES and iPS cells down a hematopoietic lineage. The phenotype and morphologies of the iPS cells were largely the same, but the iPS cells were 'extremely limited' in differentiation, expansion, and ability to form hematopoietic colonies with a greater tendency toward apoptosis [69]. Another study demonstrated that iPS cells would retain a transient epigenetic memory of their somatic origin and that this retention might limit their differentiation fates [70]. This is thought to be due to the gene expression of their cell origin and epigenetic mechanisms, including DNA methylation. How to modulate or erase this memory is not yet known [71], but continuous passaging of iPS cells appears to attenuate these differences [69]. We speculate that the use of small molecules such as inhibitors of HDAC or of DNA methyltransferase or both may help to erase the epigenetic memory and overcome some of these limitations [60,61].

Immune rejection of iPS cells was one unexpected complication in animal trials. The widely held assumption was that autologous cells would be immune-compatible and therefore protected from attack by the recipient's immune system. Zhao and colleagues [72] (2011) used teratoma formation in the same strain of mice for immune-compatibility and showed that teratomas formed by retrovirally generated iPS cells from C57BL/6 mouse fibroblasts were widely immune-rejected by C57BL/6 recipients. The study has yet to be replicated, and the causes of the immune rejection are unknown. However, the immune response was less severe when a non-integrative episomal approach was used to create the iPS cells. It was speculated that rejection of autologous cells might be due to abnormal gene expression or mutations during iPS cell generation or both [72]. Nevertheless, the immunogenicity of patient-derived iPSCs should be evaluated before autologous transplantation. There may be other practical issues to be considered before clinical application, such as whether donors shall be given the ability to withdraw their cells from study or whether they can exercise their reach-through rights for control or financial gain [73]. Regardless of these questions, scientists have already begun to collect skin biopsies from people with familial PD mutations for iPS cell generation [22]. Different genes may be altered in different individuals, and the establishment of iPS cells from different patients is the first step toward patienttailored medicine. 


\section{Conclusions}

It is clear that stem cell research has taken huge leaps in recent years, and the treatment of degenerative diseases such as PD may one day have the ability to slow down, halt, or even reverse functional decline by effectively regenerating the damaged cells or tissues. ES and iPS cell-derived DA neurons have had promising outcomes in animal trials, although there will be more challenges to overcome to make their use clinically safer. The current protocols are constantly being refined, and progress toward generating homogenous midbrain DA neurons in vitro is ongoing. It is likely that iPS cells may overtake the race of hES cells in clinical application. The use of patient-specific iPS cells in lieu of the current therapies, which simply serve to mask symptoms in many instances, may soon become a reality.

\section{Abbreviations \\ 4E-BP, eukaryotic initiation factor 4E-binding protein; 6-OHDA, 6-hydroxydopamine, DA, dopaminergic; EB, embryoid body; ES, embryonic stem; FGF, fibroblast growth factor; GDNF, glial cell line-derived neurotrophic factor; GIRK2, G protein-coupled inward-rectifying current potassium type 2: HDAC, histone deacetylase; $h E S$, human embryonic stem; iPS, induced pluripotent stem; LRRK2, leucine-rich repeat kinase 2; miRNA, micro-RNA; NURR1, nuclear receptor-related 1 protein; PD, Parkinson's disease; PET, positron emission tomography; PITX3, pituitary homeobox 3 transcription factor; SDIA, stromal cell-derived inducing activity; $\mathrm{SHH}$, sonic hedgehog; SNpc, substantia nigra pars compacta; TGF $\beta$, transforming growth factor beta; TH, tyrosine hydroxylase; UPDRS, Unified Parkinson's Disease Rating Scale; VTA, ventral tegmental area.}

\section{Competing interests}

The authors declare that they have no competing interests.

\section{Author details}

'School of Medicine, University of Aberdeen, Foresterhill, Aberdeen, AB25 2ZD, UK. ${ }^{2}$ Department of Neurosurgery, Tangdu Hospital, The Fourth Military Medical University, 1 Xinshi Road, Xi'an, Shaanxi, 710038, P.R. China. ${ }^{3}$ Regenerative Medicine Institute, School of Medicine, National University of Ireland Galway, Newcastle Road, Galway, Ireland.

\section{Published: 3 April 2012}

\section{References}

1. Jankovic J: Parkinson's disease: clinical features and diagnosis. J Neurol Neurosurg Psych 2008, 79:368-376.

2. Arenas E: Towards stem cell replacement therapies for Parkinson's disease. Biochem Biophy Res Comm 2010, 396:152-156.

3. Ang S: Transcriptional control of midbrain dopaminergic neuron development. Development 2006, 133:3499-3506.

4. Thompson L, Barraud P, Andersson E, Kirik D, Björklund A: Identification of dopaminergic neurons of nigral and ventral tegmental area subtypes in grafts of fetal ventral mesencephalon based on cell morphology, protein expression, and efferent projections. J Neurosci 2005, 25:6467-6477.

5. Guzman JN, Sanchez-Padilla J, Wokosin D, Kondapalli J, Ilijic E, Schumacker PT, Surmeier DJ: Oxidant stress evoked by pacemaking in dopaminergic neurons is attenuated by DJ-1. Nature 2010, 468:696-700.

6. Kordower JH, Freeman TB, Snow BJ, Vingerhoets FJ, Mufson EJ, Sanberg PR, Hauser RA, Smith DA, Nauert GM, Perl DP, Olanow CW: Neuropathological evidence of graft survival and striatal reinnervation after the transplantation of fetal mesencephalic tissue in a patient with Parkinson's disease. N Engl J Med 1995, 332:1118-1124.

7. Piccini P, Brooks DJ, Björklund A, Gunn RN, Grasby PM, Rimoldi O, Brundin P, Hagell $\mathrm{P}$, Rehncrona S, Widner H, Lindvall O: Dopamine release from nigral transplants visualized in vivo in a Parkinson's patient. Nat Neurosci 1999, 2:1137-1140.
8. Freed CR, Greene PE, Breeze RE, Tsai WY, DuMouchel W, Kao R, Dillon S, Winfield H, Culver S, Trojanowski JQ, Eidelberg D, Fahn S: Transplantation of embryonic dopamine neurons for severe Parkinson's disease. N Engl J Med 2001, 344:710-719.

9. Olanow CW, Goetz CG, Kordower JH, Stoessl AJ, Sossi V, Brin MF, Shannon KM Nauert GM, Perl DP, Godbold J, Freeman TB: A double-blind controlled trial of bilateral fetal nigral transplantation in Parkinson's disease. Ann Neurol 2003, 54:403-414.

10. Lindvall O, Kokaia Z, Martinez-Serrano A: Stem cell therapy for human neurodegenerative disorders-how to make it work. Nat Med 2004, 10:S42-S50.

11. Kordower JH, Chu Y, Hauser RA, Freeman TB, Olanow CW: Lewy body-like pathology in long-term embryonic nigral transplants in Parkinson's disease. Nat Med 2008, 14:504-506.

12. Li Y, Chen J, Wang L, Zhang L, Lu M, Chopp M: Intracerebral transplantation of bone marrow stromal cells in a 1-methyl-4-phenyl-1,2,3,6tetrahydropyridine mouse model of Parkinson's disease. Neurosci Lett 2001, 316:67-70.

13. Daadi MM, Weiss S: Generation of tyrosine hydroxylase-producing neurons from precursors of the embryonic and adult forebrain. J Neurosci 1999, 19:4484-4497.

14. Thomson JA, Itskovitz-Eldor J, Shapiro SS, Waknitz MA, Swiergiel JJ, Marshall VS, Jones JM: Embryonic stem cell lines derived from human blastocysts. Science 1998, 282:1145-1147.

15. Roy NS, Cleren C, Singh SK, Yang L, Beal MF, Goldman SA: Functional engraftment of human ES cell-derived dopaminergic neurons enriched by coculture with telomerase-immortalized midbrain astrocytes. Nat Med 2006, 12:1259-1268.

16. Yang D, Zhang ZJ, Oldenburg M, Ayala M, Zhang SC: Human embryonic stem cell-derived dopaminergic neurons reverse functional deficit in Parkinsonian rats. Stem Cells 2008, 26:55-63.

17. Brederlau A, Correia AS, Anisimov SV, Elmi M, Paul G, Roybon L, Morizane A, Bergquist F, Riebe I, Nannmark U, Carta M, Hanse E, Takahashi J, Sasai Y, Funa K, Brundin P, Eriksson PS, Li JY: Transplantation of human embryonic stem cell-derived cells to a rat model of Parkinson's disease: effect of in vitro differentiation on graft survival and teratoma formation. Stem Cells 2006, 24:1433-1440

18. Wernig M, Zhao J, Pruszak J, Hedlund E, Fu D, Soldner F, Broccoli V, Constantine-Paton M, Isacson O, Jaenisch R: Neurons derived from reprogrammed fibroblasts functionally integrate into the fetal brain and improve symptoms of rats with Parkinson's disease. Proc Natl Acad Sci U S A 2008, 105:5856-5861.

19. Cho MS, Lee YE, Kim JY, Chung S, Cho YH, Kim DS, Kang SM, Lee H, Kim MH Kim JH, Leem JW, Oh SK, Choi YM, Hwang DY, Chang JW, Kim DW: Highly efficient and large-scale generation of functional dopamine neurons from human embryonic stem cells. Proc Natl Acad Sci U S A 2008, 105:3392-3397.

20. Kim JH, Auerbach JM, Rodríguez-Gómez JA, Velasco I, Gavin D, Lumelsky N, Lee SH, Nguyen J, Sánchez-Pernaute R, Bankiewicz K, McKay R: Dopamine neurons derived from embryonic stem cells function in an animal model of Parkinson's disease. Nature 2002, 418:50-56.

21. Hargus G, Cooper O, Deleidi M, Levy A, Lee K, Marlow E, Yow A, Soldner F, Hockemeyer D, Hallett PJ, Osborn T, Jaenisch R, Isacson O: Differentiated Parkinson patient-derived induced pluripotent stem cells grow in the adult rodent brain and reduce motor asymmetry in Parkinsonian rats. Proc Natl Acad Sci U SA 2010, 107:15921-15926.

22. Swistowski A, Peng J, Liu Q, Mali P, Rao MS, Cheng L, Zeng X: Efficient generation of functional dopaminergic neurons from human induced pluripotent stem cells under defined conditions. Stem Cells 2010, 28:1893-1904.

23. Björklund LM, Sánchez-Pernaute R, Chung S, Andersson T, Chen IY, McNaught KS, Brownell AL, Jenkins BG, Wahlestedt C, Kim KS, Isacson O: Embryonic stem cells develop into functional dopaminergic neurons after transplantation in a Parkinson rat model. Proc Natl Acad Sci U S A 2002, 99:2344-2349.

24. Blandina P, Goldfarb J, Craddock-Royal B, Green JP: Release of endogenous dopamine by stimulation of 5-hydroxytryptamine3 receptors in rat striatum. J Pharmacol Exp Ther 1989, 251:803-809.

25. Takahashi K, Yamanaka S: Induction of pluripotent stem cells from mouse embryonic and adult fibroblast cultures by defined factors. Cell 2006, 126:663-676

26. Takahashi K, Tanabe K, Ohnuki M, Narita M, Ichisaka T, Tomoda K, Yamanaka S: 
Induction of pluripotent stem cells from adult human fibroblasts by defined factors. Cell 2007, 131:861-872.

27. Cooper O, Hargus G, Deleidi M, Blak A, Osborn T, Marlow E, Lee K, Levy A, Perez-Torres E, Yow A, Isacson O: Differentiation of human ES and Parkinson's disease iPS cells into ventral midbrain dopaminergic neurons requires a high activity form of SHH, FGF8a and specific regionalization by retinoic acid. Mol Cell Neurosci 2010, 45:258-266.

28. Kawasaki H, Mizuseki K, Nishikawa S, Kaneko S, Kuwana Y, Nakanishi S, Nishikawa SI, Sasai Y: Induction of midbrain dopaminergic neurons from ES cells by stromal cell-derived inducing activity. Neuron 2000, 28:31-40.

29. Swistowska AM, da Cruz AB, Han Y, Swistowski A, Liu Y, Shin S, Zhan M, Rao $M S$, Zeng X: Stage-specific role for shh in dopaminergic differentiation of human embryonic stem cells induced by stromal cells. Stem Cells Dev 2010, 19:71-82.

30. Perrier AL, Tabar V, Barberi T, Rubio ME, Bruses J, Topf N, Harrison NL, Studer L: Derivation of midbrain dopamine neurons from human embryonic stem cells. Proc Natl Acad Sci U S A 2004, 101:12543-12548.

31. Vazin T, Chen J, Lee CT, Amable R, Freed WJ: Assessment of stromal-derived inducing activity in the generation of dopaminergic neurons from human embryonic stem cells. Stem Cells 2008, 26:1517-1525.

32. Fasano CA, Chambers SM, Lee G, Tomishima MJ, Studer L: Efficient derivation of functional floor plate tissue from human embryonic stem cells. Cell Stem Cell 2010, 6:336-347.

33. Kriks S, Shim JW, Piao J, Ganat YM, Wakeman DR, Xie Z, Carrillo-Reid L, Auyeung G, Antonacci C, Buch A, Yang L, Beal MF, Surmeier DJ, Kordower JH, Tabar V, Studer L: Dopamine neurons derived from human ES cells efficiently engraft in animal models of Parkinson's disease. Nature 2011, 480:547-551.

34. Imai Y, Gehrke S, Wang HQ, Takahashi R, Hasegawa K, Oota E, Lu B: Phosphorylation of $4 \mathrm{E}-\mathrm{BP}$ by LRRK2 affects the maintenance of dopaminergic neurons in Drosophila. EMBO 2008, 27:2432-2443.

35. Tain LS, Mortiboys H, Tao RN, Ziviani E, Bandmann O, Whitworth AJ: Rapamycin activation of $4 \mathrm{E}-\mathrm{BP}$ prevents parkinsonian dopaminergic neuron loss. Nat Neurosci 2009, 12:1129-1135.

36. Huang $T$, Liu Y, Huang M, Zhao $X$, Cheng L: Wnt1-cre-mediated conditional loss of Dicer results in malformation of the midbrain and cerebellum and failure of neural crest and dopaminergic differentiation in mice. $J \mathrm{Mo} / \mathrm{Cell}$ Biol 2010, 2:152-163.

37. Kim J, Inoue K, Ishii J, Vanti WB, Voronov SV, Murchison E, Hannon G, Abeliovich A: A microRNA feedback circuit in midbrain dopamine neurons. Science 2007, 317:1220-1224

38. Doxakis E: Post-transcriptional regulation of alpha-synuclein expression by mir-7 and mir-153. J Biol Chem 2010, 285:12726-12734.

39. Junn E, Lee KW, Jeong BS, Chan TW, Im JY, Mouradian MM: Repression of alpha-synuclein expression and toxicity by microRNA-7. Proc Natl Acad SC USA 2009, 106:13052-13057.

40. Pfisterer U, Kirkeby A, Torper O, Wood J, Nelander J, Dufour A, Björklund A, Lindvall O, Jakobsson J, Parmar M: Direct conversion of human fibroblasts to dopaminergic neurons. Proc Natl Acad SciU S A 2011, 108:10343-10348.

41. Caiazzo M, Dell'Anno MT, Dvoretskova E, Lazarevic D, Taverna S, Leo D, Sotnikova TD, Menegon A, Roncaglia P, Colciago G, Russo G, Carninci P, Pezzoli G, Gainetdinov RR, Gustincich S, Dityatev A, Broccoli V: Direct generation of functional dopaminergic neurons from mouse and human fibroblasts. Nature 2011, 476:224-227.

42. Shao L, Feng W, Sun Y, Bai H, Liu J, Currie C, Kim J, Gama R, Wang Z, Qian Z, Liaw L, Wu WS: Generation of iPS cells using defined factors linked via the self-cleaving 2A sequences in a single open reading frame. Cell Res 2009, 19:296-306.

43. Okita K, Ichisaka T, Yamanaka S: Generation of germline-competent induced pluripotent stem cells. Nature 2007, 448:313-317.

44. Soldner F, Hockemeyer D, Beard C, Gao Q, Bell GW, Cook EG, Hargus G, Blak A, Cooper O, Mitalipova M, Isacson O, Jaenisch R: Parkinson's disease patientderived induced pluripotent stem cells free of viral reprogramming factors. Cell 2009, 136:964-977.

45. Kaji K, Norrby K, Paca A, Mileikovsky M, Mohseni P, Woltjen K: Virus-free induction of pluripotency and subsequent excision of reprogramming factors. Nature 2009, 458:771-775.

46. Okita K, Nakagawa M, Hyenjong H, Ichisaka T, Yamanaka S: Generation of mouse induced pluripotent stem cells without viral vectors. Science 2008, 322:949-953.

47. Yu J, Hu K, Smuga-Otto K, Tian S, Stewart R, Slukvin II, Thomson JA: Human induced pluripotent stem cells free of vector and transgene sequences. Science 2009, 324:797-801.

48. Jia F, Wilson KD, Sun N, Gupta DM, Huang M, Li Z, Panetta NJ, Chen ZY, Robbins RC, Kay MA, Longaker MT, Wu JC: A nonviral minicircle vector for deriving human iPS cells. Nat Meth 2010, 7:197-199.

49. Yu J, Vodyanik MA, Smuga-Otto K, Antosiewicz-Bourget J, Frane JL, Tian S, Nie J, Jonsdottir GA, Ruotti V, Stewart R, Slukvin II, Thomson JA: Induced pluripotent stem cell lines derived from human somatic cells. Science 2007, 318:1917-1920.

50. Nakagawa M, Koyanagi M, Tanabe K, Takahashi K, Ichisaka T, Aoi T, Okita K, Mochiduki Y, Takizawa N, Yamanaka S: Generation of induced pluripotent stem cells without Myc from mouse and human fibroblasts. Nat Biotech 2008, 26:101-106.

51. Kim JB, Sebastiano V, Wu G, Araúzo-Bravo MJ, Sasse P, Gentile L, Ko K, Ruau D, Ehrich M, van den Boom D, Meyer J, Hübner K, Bernemann C, Ortmeier C, Zenke M, Fleischmann BK, Zaehres H, Schöler HR: Oct4-induced pluripotency in adult neural stem cells. Cell 2009, 136:411-419.

52. Kim D, Kim CH, Moon Jl, Chung YG, Chang MY, Han BS, Ko S, Yang E, Cha KY, Lanza R, Kim KS: Generation of human induced pluripotent stem cells by direct delivery of reprogramming proteins. Cell Stem Cell 2009, 4:474-476.

53. Hochedlinger K, Yamada Y, Beard C, Jaenisch R: Ectopic expression of Oct-4 blocks progenitor-cell differentiation and causes dysplasia in epithelial tissues. Cell 2005, 121:465-477.

54. Foster KW, Liu Z, Nail CD, Li X, Fitzgerald TJ, Bailey SK, Frost AR, Louro ID, Townes TM, Paterson AJ, Kudlow JE, Lobo-Ruppert SM, Ruppert JM: Induction of KLF4 in basal keratinocytes blocks the proliferationdifferentiation switch and initiates squamous epithelial dysplasia. Oncogene 2005, 24:1491-1500

55. Xu L, Tan YY, Ding JQ, Chen SD: The iPS technique provides hope for Parkinson's disease treatment. Stem Cell Rev Rep 2010, 6:398-404.

56. Zhou H, Wu S, Joo JY, Zhu S, Han DW, Lin T, Trauger S, Bien G, Yao S, Zhu Y, Siuzdak G, Schöler HR, Duan L, Ding S: Generation of induced pluripotent stem cells using recombinant proteins. Cell Stem Cell 2009, 4:381-384.

57. Rhee YH, Ko JY, Chang MY, Yi SH, Kim D, Kim CH, Shim JW, Jo AY, Kim BW, Lee H, Lee SH, Suh W, Park CH, Koh HC, Lee YS, Lanza R, Kim KS, Lee SH: Proteinbased human iPS cells efficiently generate functional dopamine neurons and can treat a rat model of Parkinson disease. J Clin Invest 2011 , 121:2326-2335.

58. Yu J, Chau KF, Vodyanik MA, Jiang J, Jiang Y: Efficient feeder-free episomal reprogramming with small molecules. PLoS One 2011, 6:e17557.

59. Lyssiotis CA, Foreman RK, Staerk J, Garcia M, Mathur D, Markoulaki S, Hanna J, Lairson LL, Charette BD, Bouchez LC, Bollong M, Kunick C, Brinker A, Cho CY, Schultz PG, Jaenisch R: Reprogramming of murine fibroblasts to induced pluripotent stem cells with chemical complementation of Klf4. Proc Nat Acad Sci U S A 2009, 106:8912-8917.

60. Ichida JK, Blanchard J, Lam K, Son EY, Chung JE, Egli D, Loh KM, Carter AC, Di Giorgio FP, Koszka K, Huangfu D, Akutsu H, Liu DR, Rubin LL, Eggan K: A small-molecule inhibitor of tgf-Beta signaling replaces sox 2 in reprogramming by inducing nanog. Cell Stem Cell 2009, 5:491-503.

61. Pasha Z, Haider HKh, Ashraf M: Efficient non-viral reprogramming of myoblasts to stemness with a single small molecule to generate cardiac progenitor cells. PLoS One 2011, 6:e23667.

62. Schapira A: Mitochondrial disease. Lancet 2006, 386:70-82

63. Wood-Kaczmar A, Gandhi S, Wood NW: Understanding the molecular causes of Parkinson's disease. Trends Mol Med 2006, 12:521-528.

64. Belin AC, Westerlund M: Parkinson's disease: a genetic perspective. FEBS J 2008, 275:1377-1383

65. Soldner F, Laganière J, Cheng AW, Hockemeyer D, Gao Q, Alagappan R, Khurana V, Golbe LI, Myers RH, Lindquist S, Zhang L, Guschin D, Fong LK, Vu BJ, Meng X, Urnov FD, Rebar EJ, Gregory PD, Zhang HS, Jaenisch R: Generation of isogenic pluripotent stem cells differing exclusively at two early onset Parkinson point mutations. Cell 2011, 146:318-331.

66. Devine MJ, Ryten M, Vodicka P, Thomson AJ, Burdon T, Houlden H, Cavaleri F, Nagano M, Drummond NJ, Taanman JW, Schapira AH, Gwinn K, Hardy J, Lewis PA, Kunath T: Parkinson's disease induced pluripotent stem cells with triplication of the $a$-synuclein locus. Nat Commun 2011, 2:440.

67. Nguyen HN, Byers B, Cord B, Shcheglovitov A, Byrne J, Gujar P, Kee K, Schüle B, Dolmetsch RE, Langston W, Palmer TD, Pera RR: LRRK2 mutant iPSC-derived DA neurons demonstrate increased susceptibility to oxidative stress. Cell Stem Cell 2011, 8:267-280

68. Kim K, Doi A, Wen B, Ng K, Zhao R, Cahan P, Kim J, Aryee MJ, Ji H, Ehrlich LI, 
Yabuuchi A, Takeuchi A, Cunniff KC, Hongguang H, McKinney-Freeman S, Naveiras O, Yoon TJ, Irizarry RA, Jung N, Seita J, Hanna J, Murakami P, Jaenisch R, Weissleder R, Orkin SH, Weissman IL, Feinberg AP, Daley GQ: Epigenetic memory in induced pluripotent stem cells. Nature 2010, 467:285-290.

69. Feng Q, Lu SJ, Klimanskaya I, Gomes I, Kim D, Chung Y, Honig GR, Kim KS, Lanza R: Hemangioblastic derivatives from human induced pluripotent stem cells exhibit limited expansion and early senescence. Stem Cells 2010, 28:704-712

70. Polo JM, Liu S, Figueroa ME, Kulalert W, Eminli S, Tan KY, Apostolou E, Stadtfeld M, Li Y, Shioda T, Natesan S, Wagers AJ, Melnick A, Evans T, Hochedlinger K: Cell type of origin influences the molecular and functional properties of mouse induced pluripotent stem cells. Nat Biotech 2010, 28:848-855

71. Baumann K: Stem cells: holding on to the memories. Nat Rev Mol Cell Biol 2010, 11:601.
72. Zhao T, Zhang ZN, Rong Z, XuY: Immunogenicity of induced pluripotent stem cells. Nature 2011, 474:212-215.

73. Zarzeczny A, Scott C, Hyun I, Bennett J, Chandler J, Chargé S, Heine H, Isasi R, Kato K, Lovell-Badge R, McNagny K, Pei D, Rossant J, Surani A, Taylor PL, Ogbogu U, Caulfield T: iPS cells: mapping the policy issues. Cell 2009, 139:1032-1037.

doi:10.1186/scrt102

Cite this article as: Gibson ASJ, et al:: Progress on stem cell research towards the treatment of Parkinson's disease. Stem Cell Research \& Therapy 2012, 3:11. 